\title{
СТАНОВИЩЕ МОЛОДІЖНОГО ПІДПРИЄМНИЦТВА В УМОВАХ КАРАНТИННИХ ОБМЕЖЕНЬ (ЗА РЕЗУЛЬТАТАМИ ДОСЛІДЖЕНЬ 2020 РОКУ)
}

\section{Сірий Євген Володимирович}

Доктор соціологічних наук, професор, ДУ «Державний інститут сімейної та молодіжної політики», м. Київ, Україна

ORCID: 0000-0003-3396-8168

socio1@ukr.net
Надіслано:

16.03.2021

Рецензовано:

12.04.2021

Прийнято:

30.04.2021

В матеріалі висвітлюється одна із сьогоденних проблем молодіжного підприємництва і самозайнятості в Україні - їх становище та перспективи в умовах карантинних обмежень в оцінці рольової участі держави. Де-юре держава відреагувала на певні виклики пандемї у розвитку малого підприємництва (молодіжного): від законодавчої бази, програм, організацій, до окремих конкретних заходів локального характеру. Однак відповідні заходи з боку влади, особливо у порівнянні з іншими країнами, вимагають більшої ефективності. Ці висновки підтверджуються даними окремих відповідних соціологічних досліджень, що представлені в статті. На емпіричному матеріалі показано основні тренди у розвитку малого бізнесу (молодіжного) за умов карантинних обмежень, оцінку рольової участі держави у вирішенні відповідних проблем.

Ключові слова: пандемія; COVID-19; проблеми розвитку молодіжного підприємництва; державна допомога; оцінювання.

\section{Вступ}

Проблематика розвитку молодіжного підприємництва є однією із найменш вивчених у сфері молодіжної політики. Причини тут різні, i ïх небагато. Однак однією із головних $є$ неналежна увага з боку держави. Іншою - практична відсутність первинної соціальної інформації щодо функціонування цього соціального сегменту.

Пандемія COVID-19, що захлиснула все суспільство по всім сферам життєдіяльності суттєво вдаряє по малому бізнесу. Базуючись на системі особистий комунікацій він вимушений сильно обмежувати власну 
функціональність. У більшості країн світу влада проявляє велику турботу для цієї сфери. Україна, як показує практика, поступається такою увагою. Фрагментальні інформаційні дані певним чином відображають реальну картину в Україні.

\section{Аналіз останніх досліджень і публікацій}

у подібному науково-джерельному сегменті увагу привертають нечисленні опитувальні дослідження, серед яких варто назвати: опитування вітчизняного бізнесу для з'ясування оцінки впливу пандемії на власні компанії Спілкою Українських Підприємців (СУП)та Evropean Busines Association (березень-квітень 2020 р.); комплексне соціологічне дослідження «Як живе молодь України у час COVID-19», підготовлене за фінансової підтримки Програми розвитку ООН в Україні та Міністерства закордонних справ Данії; окремі науково-дослідні роботи Державного інституту сімейної та молодіжної політики (квітень-травень, жовтень 2020 р.).

\section{Формулювання цілей статті}

На прикладах окремих соціологічних досліджень показати характерні параметри становища MПіС за умов пандемії COVID-19 в оцінці державної допомоги у цій сфері.

Матеріал сформовано за даними кількох соціологічних досліджень підприємців (молодих підприємців і само зайнятих), які поповнюють і без того низький інформативний рівень висвітлення сфери державного сприяння розвитку молодіжного підприємництва і самозайнятості за умов пандемії COVID-19.

\section{Виклад основного матеріалу дослідження}

Запровадження карантинних заходів у зв'язку з пандемією сильно відобразилося на різних соціальних сферах. I досить суттєво вдарило це по дрібному бізнесу. I як показала практика, карантинні обмеження по-різному відобразилися на діяльності дрібного бізнесу загалом, так і молодіжного його сегменту зокрема. У такій складній ситуації багато хто з підприємців думав про закриття своєї справи. Більшості серед тих, хто працював у сфері обслуговування та продажу товарів, довелося закрити свої заклади, призупинити свою діяльність. Це обумовлено тим, що малий бізнес в основному грунтується на комунікації і контактах, тому не всі його сектори мали можливість працювати в умовах карантину. Багато хто навіть тоді кредитували мінусову діяльність своїх компаній, сплачуючи зарплати, податки і оплачуючи оренду [1]. У цій ситуації бізнес очікував на підтримку держави, однак їі роль у цьому питанні трактується двояко. Держава не зуміла 
ефективно підтримати бізнес. Окремі ії ініціативи (такі як «пільговий період» щодо сплати ЄСВ на період жорсткого карантину) виявилися нефункціональними через провал у комунікації. Як наслідок, власники бізнесу були змушені сплачувати податки, незважаючи на відсутність доходів.

Найбільше підприємців (йдеться про всіх) турбувало невизначеність поточної ситуації. В умовах, коли важко передбачити тривалість карантину $\mathrm{i}$ суттєві обмеження в поведінці споживачів, прораховувати будь-які сценарії розвитку свого бізнесу практично неможливо. За даними Державної податкової служби, у березні 2020 р. близько 13,3 тис. підприємців-фізосіб (ФОП) припинили свою діяльність (God karantina v Ukraine - kakoi biznes zakrylsia iz-za lokdaunov, 2020; Biznes na karantine. Nazvany piat hlavnykh problem..., 2020). У квітні 2020 р., близько $29 \%$ дрібних підприємців (за даними інтернетвидання «Економічна правда») припинили роботу, що характерно для мікробізнесу, а близько $6 \%$ підприємців повністю закрили бізнес (Koronavirus VS biznes:..., 2020).

Оперативним джерелом інформації стосовно різних проблемних сторін малого бізнесу стали і окремі соціологічні опитування стосовно поточних проблем цього соціального сегменту. Так, у березні-квітні 2020 р. Спілкою Українських Підприємців (СУП)та Evropean Busines Association було проведено опитування вітчизняного бізнесу для з'ясування оцінки впливу пандемії на власні компанії. Як свідчать результати опитування, українські підприємці опинилися в складних умовах для існування (Kozhen piatyi malyi biznes mozhe..., 2020). Так, $18 \%$ респондентів-підприємців розглядали варіант закриття власного бізнесу з причини епідемії коронавірусу в країні. Ще 78\% повідомили про втрату $3 / 4$ своїх доходів. Було відзначено, що уповільнення бізнесактивності в умовах карантину призводить до скорочення штату і зарплати персоналу. Третина респондентів заявляла про падіння доходів на 90-100 \% 3 початку карантину, що призвело до скорочення до половини персоналу. Зокрема, $41 \%$ опитаних планували зменшити зарплати, $42 \%$ опитаних підприємців частково або повністю скоротили свій штат, 63 \% - прогнозували скорочення до кінця карантину (Kozhen piatyi malyi biznes mozhe..., 2020). Тільки $3 \%$ респондентів вказали, що їх бізнес може працювати тривалий час за необхідних умов (орендні канікули, віддалений доступ для співробітників тощо). Однак, це стосувалося тільки юридичних осіб підприємництва.

Додатковим і доповнювальним джерелом інформації до немобільної статистичної звітності щодо діяльності цієї сегментної групи виявилися й інші

$\overline{\text { (С)ірий Є. В., } 2021}$ 


\section{Міжнародні відносини: теоретико-практичні аспекти \\ Випуск 7 (2021) \\ ISSN (print) 2616-745X; ISSN (online) 2616-7794}

окремі соціологічні дослідження. Так, згідно результатів комплекного соціологічного дослідження «Як живе молодь України у час COVID-19» (Yak zhyve molod Ukrainy..., 2020), вплив пандемії COVID-19 на бізнес молоді виявився катастрофічним. Майже 43 \% власників бізнесу зазначили, що їхній бізнес або закрито, або він перебуває на межі закриття.

Цьому питанню були присвячені окремі науково-дослідні роботи Державного інституту сімейної та молодіжної політики. Інститутом у квітні-травні 2020 р. було проведено соціологічне опитування представників молодіжного сегменту малого бізнесу з метою вивчення окремих проблем його розвитку, труднощів ведення малого бізнесу та оцінка зусиль держави за обставин запровадження карантинних обмежень у зв'язку 3 пандемією короновіруса (COVID-19). Дослідження проводилося шляхом поєднання методики онлайн-опитування та телефонного опитування. Валідність вимірювальних ознак базувалася не на репрезентативності вибірки, а на характері оцінки досліджуваних проблем молодіжного підприємництва та самозайнятості. Дослідження носило розвідувально-описовий характер.

У рамках дослідження було опитано молодих підприємців та само зайнятих осіб віком від 16 до 34 років. Більшість опитаних становили особи чоловічої статі (71,4\% чоловіків проти $27,6 \%$ жінок). За формою підприємницької діяльності, юридичні особи підприємництва становили $27,6 \%$, ФОП -58,6\%, самозайняті особи $-13,8$ \%. Більшість опитаних за сферою діяльностіналежала до представників торгівлі, сфери обслуговування і надання послуг.

За результатами нашого дослідження кожен четвертий респондент $(24,1 \%)$ зазначив про закриття свого бізнесу під час карантину. Половина вказували на те, що їхній бізнес продовжував частково функціонувати: $24,1 \%$ - про суттєве згортання, але на час карантину їхній бізнес функціонує; 31,1 \% - частково згорнувся. I кожен п'ятий респондент-підприємець відповів, що його бізнес функціонує в повному обсязі (див. рис. 1).

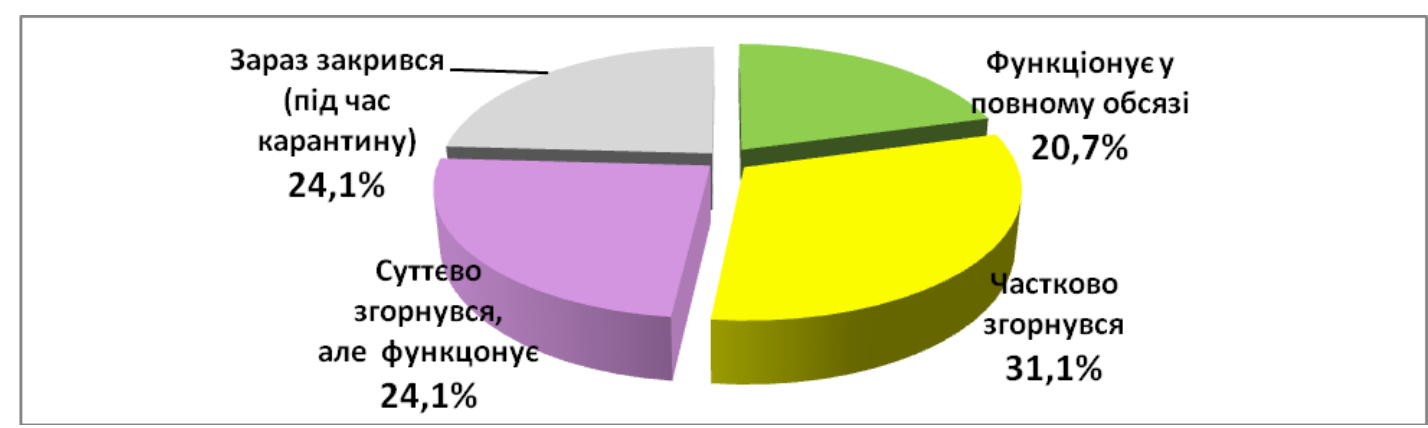

Рис. 1. Функціонування власного бізнесу під час карантину (\%). 
Це також підтверджують результати інших досліджень. Зокрема дослідження Європейської бізнес асоціації, що проведено у березні 2020 р. свідчить, що близько $18 \%$ представників дрібного бізнесу мали намір згортати свою діяльність через епідемію короновірусу (COVID-19) в країні, а $22 \%$ згорнули підприємницьку діяльність через карантин (Kozhen piatyi malyi biznes mozhe..., 2020). Хоча, згідно результатів нашого дослідження (дослідження не $\epsilon$ репрезентативним через специфіку вибірки, однак його розвідувального характеру і підтверджені іншими дослідженнями дані виявляють імовірно об'єктивну ситуацію), у більшої половини респондентів-підприємців непогано йшли справи до введення карантинних обмежень (див. рис.2).

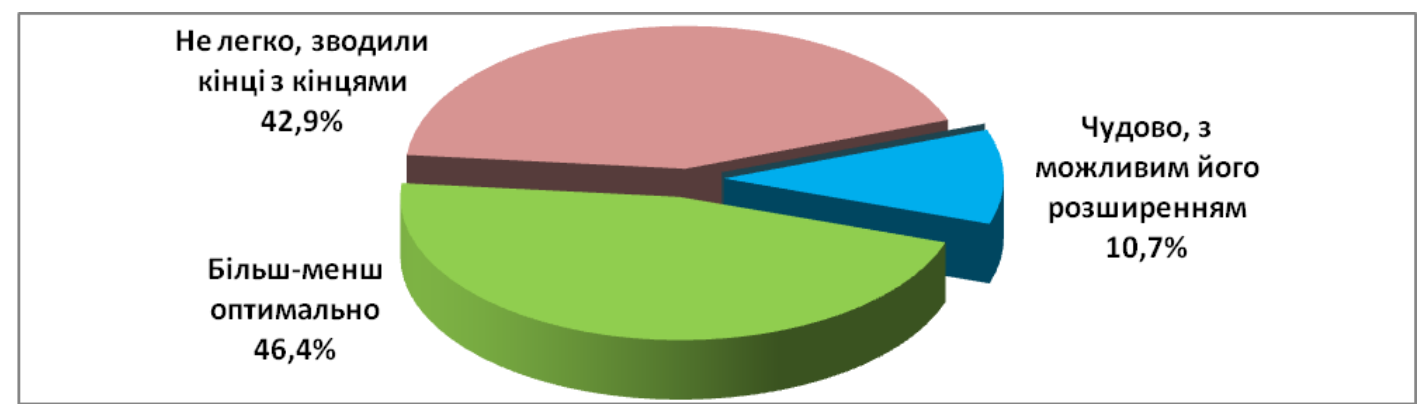

\footnotetext{
Рис. 2. Оцінка рівня розвитку власного бізнесу до карантину (за оцінкою респондентів), (\%).
}

Сама пандемія та відповідні заходи з боку влади досить сильно обмежили діяльність цієї сфери. Серед труднощів, які виникли у веденні бізнесу через карантинні обмеження (згідно результатів дослідження ДІСМП), молоді підприємці та самозайняті переважно зазначили зниження активності тих сфер, від яких залежав їх бізнес, затримку «платіжок», закриття постачальних точок, обмеження спілкування з замовниками, що породило непевність у подальших замовленнях $(27,3 \%)$ та відсутність контактів, суспільної активності, обмеженість відвідування клієнтів $(24,2 \%)$. Крім того, респонденти до труднощів, пов'язаних з введенням карантину, відносили:

- відсутність попиту та замовлень (15,3\%);

- неможливість повним обсягом реалізовувати товар, зниження купівельної спроможності (12,1 \%);

- закриття торгівельних точок, що негативно відображається на продажах, та карантинні обмеження (12,1\%);

- додаткові витрати на засоби захисту (3\%);

$\overline{\text { (с)ірий Є. В., } 2021}$ 


\section{Міжнародні відносини: теоретико-практичні аспекти \\ Випуск 7 (2021) \\ ISSN (print) 2616-745X; ISSN (online) 2616-7794}

- пасивність влади при карантині, що загалом негативно відображалося на діяльності підприємців (3\%) та інше (3\%).

У доповненні цього питання представники молодіжного підприємництва та самозайнятої молоді вказували на різні перешкоди у розвитку їх господарської діяльності під час карантину. Серед таких, що заважали розвитку бізнесу під час карантину через епідемію (COVID-19), найчастіше вказувалося на різні карантинні обмеження для населення $(62,2 \%)$, відсутність попиту $(44,8 \%)$, закриття тих сфер, від яких залежить їхній бізнес $(37,9 \%)$ та неможливість працювати дистанційно (34,5%) (див. табл. 1).

Таблищя 1

\section{Основні перешкоди (за оцінкою респондентів) у розвитку власного бізнесу під час карантину (\%)}

\begin{tabular}{|l|c|}
\hline Різні карантинні обмеження для населення & 65,6 \\
\hline Відсутність попиту & 44,8 \\
\hline Закриття (зниження активності) тих сфер, від яких залежить їх бізнес & 37,9 \\
\hline Неможливість працювати дистанційно & 34,5 \\
\hline Закриття приміщень, торгівельних майданчиків & 27,6 \\
\hline Проблеми реалізації товару & 24,1 \\
\hline $\begin{array}{l}\text { Відсутність (зниження) соціальної комунікації між партнерами, } \\
\text { підлеглими тощо }\end{array}$ & 20,7 \\
\hline Відсутність обігових коштів & 17,2 \\
\hline Транспортно-логістичні ускладнення & 10,3 \\
\hline Неможливість обслуговувати кредити & 3,4 \\
\hline Карантинні обмеження для діяльності & 3,4 \\
\hline Безлад в країні & 3,4 \\
\hline
\end{tabular}

*Питання з альтернативами, ऽ> $100 \%$.

Звісно, можна говорити, що структура і розподіл таких проблемних чинників залежить від розподілу сфер діяльності опитуваних підприємців. Ці дані хоч і високим рівнем не репрезентують дійсну картину, але доволі чітко характеризують і відображають суть і зміст проблем у молодіжному підприємницькому середовищі у цей період.

За результатами комплексного соціологічного дослідження «Як живе молодь України у час COVID-19», негативними наслідками карантину стали скорочення оборотних коштів (через падіння попиту, збитки, простій, оплату 
оренди під час простою тощо); необхідність пошуку нових постачальників, партнерів; потреба зміни бізнес-моделі; втрата приміщення для надання послуг (у зв'язку із закриттям торговельно-розважальних центрів, або через вимогу оплачувати оренду підчас простою); необхідність інвестувати кошти в переведення бізнесу в онлайн. Проте 64,6 \% власників вказали, що їхній бізнес неможливо перевести в онлайн, а 12,5\% могли б, але не хочуть змінювати формат роботи (Yak zhyve molod Ukrainy..., 2020).

Результати опитування Спілкою підприємців України (СУП) демонстрували необхідність запровадження радикальних заходів з боку влади на підтримку економіки, зокрема, таких як тимчасове звільнення від сплати податків бізнесу. Зокрема мова йшла про необхідність позбавлення мікробізнесу зайвого навантаження, а саме: звільнення від обов'язкової сплати ЄСВ-Фопів-сумісників та ФОП-ів, які тимчасово не провадять діяльність під час карантину (Koronavirus VS biznes..., 2020).

Одним із можливих інструментів допомоги малому та мікробізнесу молодими підприємцями вбачалася надспрощена процедура отримання кредиту і зниження вартості кредиту, розширення кредитної програми «5-7-9» для забезпечення можливості поповнення обігових коштів, придбання об’єктів нерухомості. На увазі було і перегляд норм фіксації всієї другої (річний дохід яких не перевищує 1,5 млн грн) та третьої (річний дохід яких не перевищує 5 млн грн) груп спрощеної системи оподаткування, виведення 3 під фіксації тих, кому вона економічно недоцільна, передбачити фіскалізацію тільки ризикових категорій платників (Koronavirus VS biznes..., 2020). Ще близько 10 \% представників дрібного бізнесу (за даними СУП) очікували на зменшення розмірів орендної плати. Серед інших очікуваних кроків та пропозицій до влади також визначалися компенсації втрат роботодавцям та працівникам (близько 5,5\%), державні кредити та держзамовлення (близько 5,5\%) (Ne chekaite khoroshykh novyn..., 2020).

Не можна сказати, що влада не намагалася щось робити для зменшення проблем та відповідної напруги. Було ухвалено низку законодавчих документів про зниження адміністративних та окремих фінансових зобов'язань підприємців перед державою у цей не простий для всіх період.

3 березня 2020 р. набрав чинності Закон України «Про внесення змін до Податкового кодексу України та інших законів України щодо підтримки платників податків на період здійснення заходів, спрямованих на запобігання виникненню і поширенню коронавірусної хвороби (COVID-19)» (Pro vnesennia zmin do Podatkovoho kodeksu Ukrainy..., 2020; Roziasnennia VHO APPU - 3275...,

$\overline{\text { (С)ірий Є. В., } 2021}$ 


\section{Міжнародні відносини: теоретико-практичні аспекти \\ Випуск 7 (2021) \\ ISSN (print) 2616-745X; ISSN (online) 2616-7794}

2020). Ним було передбачено встановлення мораторію на податкові перевірки; відстрочення податкових зобов'язань за річною декларацією про майновий стан і доходи за 2019 р.; «податкові канікули» з плати за землю; відсутність штрафу і пені за період «податкових канікул»; звільнення від нарахування та сплати ЄСВ (Pro vnesennia zmin do Podatkovoho kodeksu Ukrainy..., 2020; Roziasnennia VHO APPU - 3275..., 2020; Karantynni novovvedennia dlia biznesu..., 2020), зокрема, тимчасово, на період з 1 березня по 30 квітня 2020 р. звільнялися від нарахування та сплати ЄСВ такі суб'єкти підприємництва як: фізичні особи-підприємці, в тому числі ті, які обрали спрощену систему оподаткування; особи, які провадять незалежну професійну діяльність; окремі члени фермерського господарства.

У зв'язку з ухваленням цього вищезгаданого закону, у нашому дослідженні респондентам було запропоновано оцінити зусилля влади у допомозі малому бізнесу і наскільки ці відповідні зміни позитивно вплинуть на діяльність підприємців на цей період. Загалом, потрібно сказати, що ейфорії стосовно цього з боку представників цього сегменту не було (див. табл.2).

Таблиця 2

Оцінка респондентами можливостей закону про пільги для бізнесу в умовах карантину на підприємницьку діяльність (\%)

\begin{tabular}{|c|c|}
\hline Суттєво полегшать & 0,0 \\
\hline Частково полегшать & 3,4 \\
\hline Практично не полегшать & 51,8 \\
\hline Я ще не ознайомлений з цими змінами & 17,4 \\
\hline Важко відповісти & 13,6 \\
\hline Я цьому не вірю & 6,9 \\
\hline Мене це не цікавить & 6,9 \\
\hline
\end{tabular}

Серед тих, хто визначився 3 оцінкою (ледь більше половини опитуваних) зазначили, що цей закон практично нічого не полегшить (51,8 \%). Лише 3,4\% респондентів вважають, що ухвалення закону № 3220 щодо запровадження податкових i неподаткових пільг для бізнесу в умовах карантину частково полегшить ведення малого бізнесу та сприятиме самозайнятості. Серед інших (хто не міг дати цьому оцінку) кожен п'ятий ще не був ознайомлений з цим законом $(17,4 \%)$. Це показує очевидність того, що переважна більшість респондентів має великі сумніви щодо ефективності дій держави допомогти малому бізнесу шляхом запровадження певних пільг. Подібний скептицизм проявляється і в іншій оцінці. 
Також у грудні 2020 р. Верховна Рада схвалила законопроєкт про підтримку бізнесу під час карантину. Згідно цього документу в 2020-2021 pp. держава зобов'язується забезпечити виплати одноразової матеріальної допомоги по 8 тис. грн (частково виплати вже розпочалися) застрахованим особам, які можуть втратити частину зарплати або доходу в разі введення додаткових обмежувальних протиепідемічних заходів. Також передбачена виплата одноразової матеріальної допомоги бізнесу для збереження робочих місць найманих працівників, а також одноразова компенсація витрат, понесених за сплату єдиного внеску на загальнообов'язкове державне соціальне страхування.

Даним законом передбачено, що протягом терміну дії карантину та протягом шести місяців після його закінчення, суб'єкти малого та середнього підприємництва сфери громадського харчування зможуть отримати державну підтримку (Pro sotsialnu pidtrymku zastrakhovanykh osib ta subiektiv hospodariuvannia..., 202). Закон також скасовує стягнення орендної плати за договорами оренди діяльність якого була заборонена в зазначений період. Як кажуть: «час покаже», стосовно прийнятності і цього закону для підприємців. Однак, нині ми є свідками високого рівня недовіри та скептицизму з боку представників МПіС стосовно сприйняття допомоги бізнесу від держави.

Майже усі опитані $(89,6 \%$, за результатами дослідження ДІСМП) скептично сприйняли зусилля влади щодо допомоги малому бізнесу під час карантину у зв'язку з епідемією короновіруса (COVID-19). Лише 3,5\% респондентів вважають, що вона намагається немало зробити для малого (дрібного) бізнесу в цей період. I близько 7 \% посередньо оцінили зусилля влади (див. рис. 3).

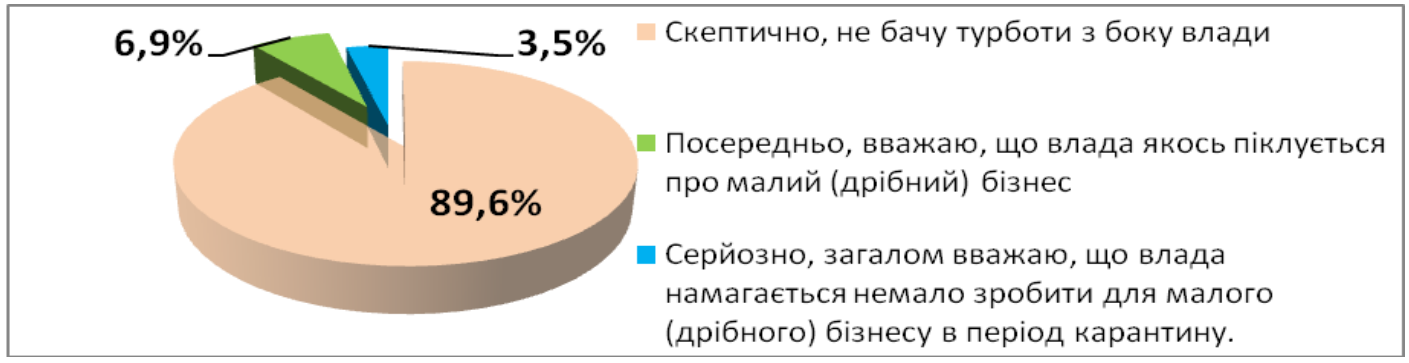

Рис. 3. Оцінка респондентів щодо зусиль влади у допомозі малому бізнесу під час карантину (\%).

$\overline{\text { (С)ірий Є. В., } 2021}$ 


\section{Міжнародні відносини: теоретико-практичні аспекти Випуск 7 (2021) ISSN (print) 2616-745X; ISSN (online) 2616-7794}

Те, що майже $90 \%$ респондентів скептично оцінила зусилля влади у допомозі малому бізнесу під час карантину, не відчуваючи іiі, $\epsilon$ досить серйозним аргументом у цій системі взаємовідносин не на користь влади, котрий вказує на їі інертність. Хоча, до того, що справді полегшило роботу засновників бізнесу, то можна зарахувати запровадження онлайн-послуг, дистанційний сервіс державних установ. Переважна частина опитаних знають про ці можливості та позитивно їх оцінюють (Yak zhyve molod Ukrainy..., 2020). Важливо й те, що апробовані сервіси ефективно функціонуватимуть і після завершення пандемії.

Чималі кроки у відстоюванні прав підприємців здійснює Спілка українських підприємців (СУП), яка на час карантину закликала владу звільнити від сплати ЄСВ та ПДФО до кінця року увесь бізнес, який не скорочує персонал в умовах простою виробництва. Мета цієї ініціативи - дати можливість роботодавцям утримати робочі місця в період існуючої кризи, що за підрахунками можна фінансово підтримати майже два мільйони своїх громадян (1408,2 тис зайнятих в юридичних осіб та 546,5 тис у ФОПів) (Yak zhyve molod Ukrainy..., 2020). Окрім тимчасового скасування ЄСВ та ПДФО, Спілка українських підприємців постійно наголошує на необхідності радикальних заходів на підтримку бізнесу. Зокрема, йдеться про надання можливості усім роботодавцям отримати часткову допомогу за своїх працівників, якщо їм скорочено час та об'єми роботи, у зв'язку із запобіганням поширенню пандемії, а також введення мораторію на всі перевірки бізнесу до кінця року, щоб підприємці мали можливість економічно «оговтатися» від кризи, а не займатися адмініструванням (Koronavirus VS biznes..., 2020). Водночас, як вважають фахівці, в ухвалених «антикризових» законах на підтримку економіки (№ 3275 «Закон про внесення змін до деяких законодавчих актів, спрямованих на забезпечення додаткових соціальних та економічних гарантій у зв'язку з поширенням коронавірусної хвороби (COVID19) та підписаному закону № 533-IX (закон «Про внесення змін до Податкового кодексу України та інших законів України щодо підтримки платників податків на період здійснення заходів, спрямованих на запобігання виникненню i поширенню коронавірусної хвороби (COVID-19), відповідні пропозиції від бізнесу так і не були враховані (Vlasti pomogli biznesu, no etogo malo..., 2020). Хоча, і на момент дії карантину, підприємці від державної влади очікували в першу чергу, фінансової підтримки. 1/3 власників бізнесу вважали, що вона має здійснюватися у формі тимчасового звільнення від сплати податків або ж, принаймні у їхньому істотному зниженні (податкові канікули, тимчасова 
відміна ЄСВ, ПДФО) (Koronavirus VS biznes..., 2020; Kozhen piatyi malyi biznes mozhe..., 2020).

Представниками різних неурядових організацій, які $\epsilon$ дотичними до регуляційної сфери інституту дрібного та середнього бізнесу було виокремлено найпоширеніші серед підприємницького сектору проблеми діяльності під час карантину, за якими були надані конструктивні, на їхню думку рекомендації.

За оцінкою фахівців, основні кроки, які б допомогли бізнесу пережити карантин, стосуються податкового послаблення та фінансового сприяння. Зокрема, йдеться про звільнення від оплати ЄСВ (єдиного соціального внеску) для ФОП; послаблення податкового навантаження у Фонд оплати праці для юридичних осіб і тимчасове утримування (часткове) вивільнених працівників; безвідсотковий кредит тим, хто закривається із ініціативи держави; запровадження податкових канікул (немає прибутку - немає податку); необхідність реальних, а не фейкових кредитів для розвитку бізнесу, так як брак обігових коштів - це буде єдина реальна проблема малого та середнього бізнесу після виходу з карантину. Усі інші вирішуються досить легко.

Ця ситуація підтверджується i результатами нашого дослідження. Третина опитаних вважає, що для підтримки малого бізнесу під час карантину у зв'язку з епідемією короновірусу (COVID-19) доречно запровадити фінансові «пільги» (35,2\%): спрощення і зниження оподаткування ФОПів; доступність нормального кредитування; дешеві і доступні кредити, надання програми сприяння бізнесу, фінансова допомога, відміна відсотків по кредитах тощо. Також третина респондентів пропонувала оптимізацію (полегшення) карантинних умов, здійснення розумних послаблень тощо $(32,4 \%)$. Також з боку респондентів були надані такі пропозиції, як такі, що конструктивно вплинуть на розвиток молодіжного підприємництва та самозайнятості. Це, зокрема:

- зняття податку та орендної плати для недієвих підприємств (11,7 \%);

- менше перевірок та «не заважати» (8,7 \%);

- більше уваги приділяти індивідуальній роботі 3 кожним підприємством (3 \%);

- активізувати дрібно-роздрібний спосіб торгівлі, сприяючи попиту для дрібних підприємців (3 \%);

- надання грантів та іншого фінансування на отримання обладнання, навчання, на створення господарсько-бізнесової діяльності (3\%);

- важко відповісти (3 \%).

$\overline{\text { ๔Сірий Є. В., } 2021}$ 
Такі ж подібні результати презентує й інше дослідження молоді «Як живе молодь України під час COVID-19», за яким молоді представники дрібного підприємництва та самозайнятих (60 \%) пропонують зменшити податкове навантаження та запровадити «податкові канікули», зменшити орендну плату $-33,3$ \%, зменшити карантинні обмеження - 29,2\%, надати грантову, проєктну підтримку $-25,0 \%$, надати пільгові кредити $-22,3$ \% (Yak zhyve molod Ukrainy..., 2020).

Попри безліч труднощів молоді представники малого бізнесу i самозайнята молодь не збираються «по своїй волі» згортати власну справу. Про це повідомило 82,8 \% опитаних, натомість у 6,9 \% респондентів виникало бажання закрити власний бізнес і змінити рід занять, а 10,3\% вагалися 3 відповіддю (див. рис. 4).

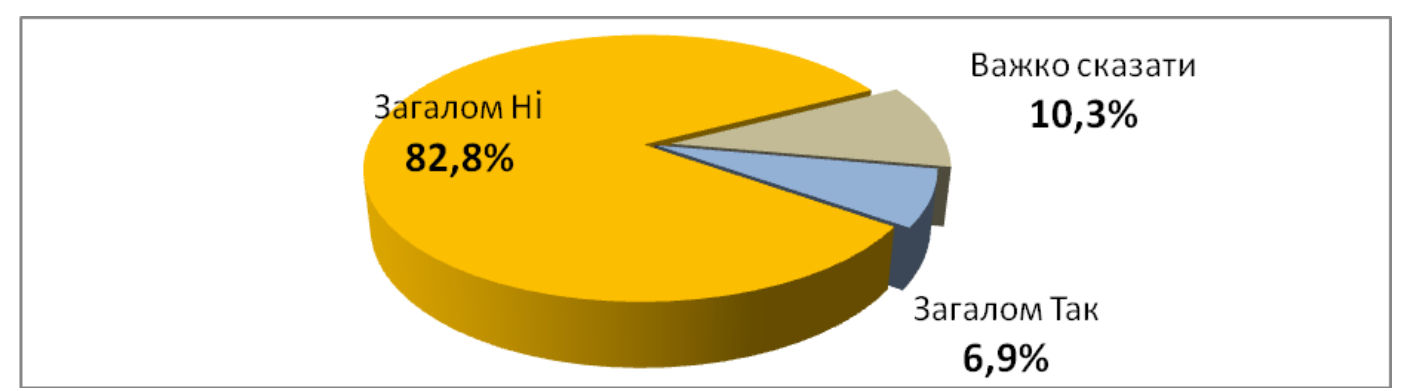

Рис. 4. Розподіл відповідей на запитання щодо бажання залишити зайняття бізнесом (як наразі обтяжливе) і змінити рід заняття (\%).

Окремим питанням в нашому дослідженні було висвітлення окремих сторін соціального аспекту діяльності молодих підприємців, зокрема, питання надання благодійної допомоги у боротьбі з COVID-19. Так, 27,7 \% опитаних надавали деяку благодійну допомогу людям чи організаціям у боротьбі з COVID-19, 6,8 \% - сприяли цьому. Натомість понад половина опитаних навіть не замислювалася про це $(55,2 \%)$, а $10,3 \%$ не мали змоги надавати таку допомогу (див. рис. 5). 


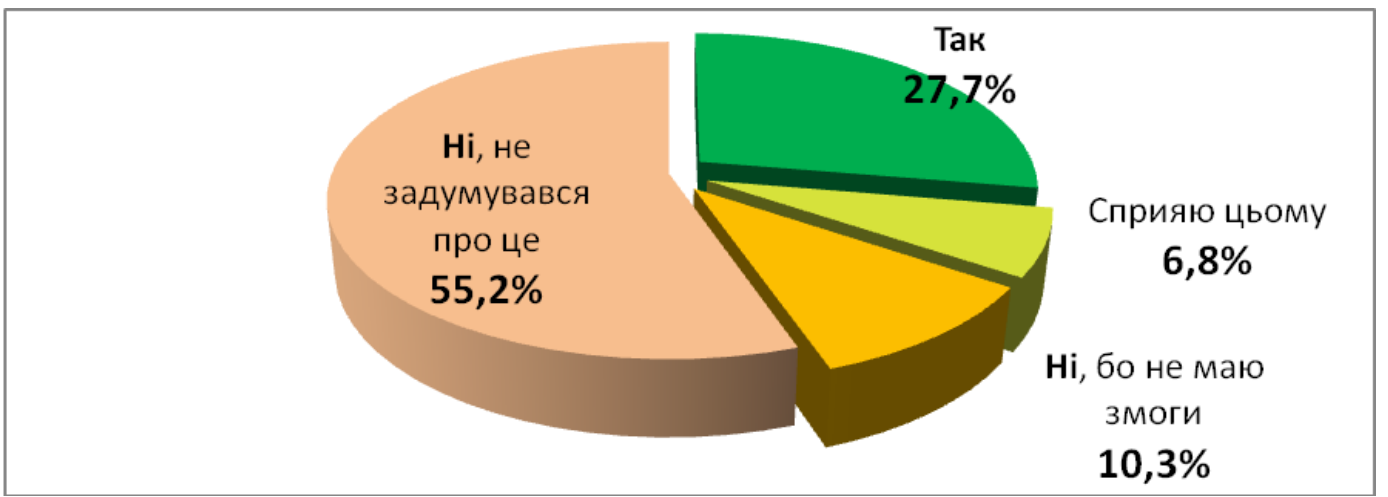

Рис. 5. Розподіл відповідей на запитання стосовно надання благодійної допомоги людям чи організаціям у боротьбі з COVID-19 (\%).

Загалом однозначні висновки про певну неохочість проявляти соціальну турботу для населення не варто, адже молодіжний прошарок дрібного бізнесу сам потребує допомоги. Це, скоріше, властиве для середнього та великого бізнесу. Усе ж, близько 1/3 (34,5 \%) респондентів відповіли, що надавали таку допомогу.

Як бачимо, нині, у період карантину, молодь, яка представляє сферу малого бізнесу зіткнулися з низкою суттєвих труднощів. Часто їхня діяльність підпадала під заборону в умовах пандемії або зазнала значних збитків через стрімке зниження попиту. Згідно досліджень можна припустити, що близько половини молодих підприємців і самозайнятої молоді продовжили частково працювати під час введення карантинних обмежень у зв'язку з епідемією короновірусу (COVID-19), тоді як кожен четвертий представник цієї сфери (згідно дослідження) зазначив про закриття власного бізнесу.

Серед труднощів, які виникли під час карантину через епідемію короновірусу (COVID-19), можна вважати зниження активності тих сфер, від яких залежав їх бізнес, зниження суспільної активності і обмеженість відвідування клієнтів, відсутність попиту і замовлень. Серед перешкод, які заважали розвитку бізнесу під час карантину, є різні карантинні обмеження для населення, на відсутність попиту, закриття тих сфер, від яких залежить їхній бізнес та неможливість працювати дистанційно.

Підприємницька самозайнята молодь виявляла недовіру до влади у зв'язку з запровадженням податкових і неподаткових пільг для бізнесу в умовах карантину. Так, половина респондентів зазначили, що цей закон практично нічого не полегшить. Майже усі опитані скептично ставляться

$\overline{\text { (C)ірий Є. В., } 2021}$ 


\section{Міжнародні відносини: теоретико-практичні аспекти \\ Випуск 7 (2021) \\ ISSN (print) 2616-745X; ISSN (online) 2616-7794}

до зусиль влади щодо допомоги малому бізнесу під час карантину у зв’язку з епідемією короновірусу (COVID-19).

\section{Висновки}

Для підтримки малого бізнесу під час карантину у зв'язку з епідемією короновірусу (COVID-19) варто, на думку представників МПіС, запровадити фінансові «пільги» та здійснити оптимізацію полегшення карантинних умов і здійснення розумних послаблень. Тому для підтримки малого та середнього бізнесу в умовах пандемії уряд має створити спеціальну програму з величезним вливанням коштів. Український уряд досі не представив реального плану виходу з кризи як для малого, так і для великого бізнесу. На думку фахівців, ми із запізненням втягнулися в пандемію, і це спричинить великі проблеми для цієї сфери, зокрема. Наша країна, мабуть, залишилася єдина, яка досі не розробила програми виходу із кризи пандемії для малого бізнесу (Vyzhyty u karantyn..., 2020; Interviu z nardepom..., 2020). I це питання залишається відкритим. Недаремно, за останні декілька місяців, як на місцевому рівні (у регіонах), так і національному (під стінами Кабміну) відбувалися акції протесту на кшталт «Карантин вбиває», «Захисти ФОП» та інші акції щодо проблемності виживання малого бізнесу.

\section{References:}

1. 'Biznes na karantine. Nazvany piat hlavnykh problem predprynimatelei' [The business is in quarantine. Five main problems of entrepreneurs are named]. (2020). Liha-Biznes [Liga-Business], [online]. Available at: https://biz.liga.net/ekonomika/all/novosti/biznes-na-karantine-nazvany-pyatglavnyh-problem-predprinimateley.

2. 'God karantina v Ukraine - kakoi biznes zakrylsia iz-za lokdaunov' [A year of quarantine in Ukraine - which business was closed due to lockdowns]. (2020). UBR [UBR], [online]. Available at: https://ubr.ua/business-practice/hod-karantina-vukraine-kakoj-biznes-zakrylsja-iz-za-lokdaunov-4000165.

3. 'Interviu z nardepom V. Hnatenkom' [Interview with People's Deputy of Ukraine V. Hnatenko]. (2020). Telekanal 'ZIK' ['ZIK' TVchannel], [online]. Available at: https://zik.ua/news/economics/nardep_hnatenko_

dlia_pidtrymky_maloho_ta_serednoho_biznesu_pid_chas_karantynu_maie_buty_stvore na_spetsialna_prohrama_967628.

4. 'Karantynni novovvedennia dlia biznesu. Yaki niuansy treba znaty?' [Quarantine innovations for business]. (2020). Derzhavna podatkova sluzhba Ukrayiny [State Tax Service of Ukraine], [online]. Available at: https://tax.gov.ua/data/material/000/322/412719/Informaciyniy_list_7.pdf. 
5. 'Koronavirus VS biznes: polovyna pidpryiemtsiv protrymaietsia na karantyni ne bilshe misiatsia' [Coronavirus VS business: half of entrepreneurs will remain in quarantine for no more than a month]. (2020). Ekonomichna pravda [Economic Truth], [online]. Available at: https://www.epravda.com.ua/publications/2020/04/2/658857/

6. 'Kozhen piatyi malyi biznes mozhe zakrytysia cherez karantyn opytuvannia EVA' [Coronavirus VS business: half of entrepreneurs will remain in quarantine for no more than a month]. (2020). EVA [EVA], [online]. Available at: https://eba.com.ua/kozhen-p-yatyj-malyj-biznes-mozhe-zakrytysya-cherezkarantyn-opytuvannya-eva/.

7. 'Ne chekaite khoroshykh novyn: yak karantyn vplyvaie na biznes v Kyievi' [Don't expect good news: how quarantine affects business in Kyiv]. (2020). Ekonomichna pravda [Economic Truth], [online]. Available at: https://www.epravda.com.ua/publications/2020/03/26/658586/.

8. Pro sotsialnu pidtrymku zastrakhovanykh osib ta subiektiv hospodariuvannia na period zdiisnennia obmezhuvalnykh protyepidemichnykh zakhodiv, zaprovadzhenykh z metoiu zapobihannia poshyrenniu na terytorii Ukrainy hostroi respiratornoi khvoroby COVID-19, sprychynenoi koronavirusom SARS-Co V2: Proekt Zakonu № 4429 vid 26 lystopada 2020 roku [On social support of insured persons and business entities for the period of implementation of restrictive antiepidemic measures introduced to prevent the spread of acute respiratory disease COVID-19 caused by coronavirus SARS-Co V-2 in Ukraine: Draft Law no. 4429 dated from November 26, 2020]. Verkhovna Rada Ukrainy, [online]. Available at: http://w1.c1.rada.gov.ua/pls/zweb2/webproc4_1?pf3511=70533.

9. Pro vnesennia zmin do Podatkovoho kodeksu Ukrainy ta inshykh zakoniv Ukrainy shchodo pidtrymky platnykiv podatkiv na period zdiisnennia zakhodiv, spriamovanykh na zapobihannia vynyknenniu i poshyrenniu koronavirusnoi khvoroby (COVID-19): Zakon Ukrainy, vid 30 bereznia 2020 roku N 540-IX, vid 13 travnia 2020 roku N 591-IX [On Amendments to the Tax Code of Ukraine and Other Laws of Ukraine on Support of Taxpayers for the Period of Measures to Prevent the Occurrence and Spread of Coronavirus Disease (COVID-19): Law of Ukraine, dated from March 30, 2020 No. 540-IX, dated from May 132020 N 591-IX]. LIHA 360 [LIGA 360], [online]. Available at: https://ips.ligazakon.net/document/view/T200533?utm_source=biz.ligazakon.net\& utm_medium=news\&utm_content=bizpress 01 .

10. 'Roziasnennia VHO APPU - 3275: novi podatkovi antykryzovi zakhody, ZMINA ranishe pryiniatykh' [Explanation of the APO - 3275: new tax anti-crisis

$\overline{\text { (С)ірий Є. В., } 2021}$ 


\section{Міжнародні відносини: теоретико-практичні аспекти \\ Випуск 7 (2021) \\ ISSN (print) 2616-745X; ISSN (online) 2616-7794}

measures, change of previously adopted]. (2020). APPU [AIEU], [online]. Available at: https://appu.org.ua/main-news/rozyasnennya-vgo-appu-3275-novi-podatkoviantikrizovi-zahodi-zmina-ranishe-prijnyatih/.

11. 'Torhovo-promyslova palata: 5 holovnykh problem $\mathrm{v}$ diialnosti biznesu pid chas karantynu ta shliakhy yikh vyrishennia' [Chamber of Commerce and Industry: 5 main problems in business during quarantine and ways to solve them]. (2020). Stalyi ekonomichnyi rozvytok [Sustainable Economic Development], [online]. Available at:https://www.auc.org.ua/novyna/tpp-5-golovnyh-problem-v-diyalnostibiznesu-pid-chas-karantynu-ta-shlyahy-yih-vyrishennya.

12. 'Vlasti pomogli biznesu, no etogo malo. Cheho ne uchel antykoronavyrusnyi paket? Razbor' [The authorities have helped the business, but this is not enough. What did the anti-coronavirus package fail to take into account? Looking into in details]. (2020), Liha-Biznes [League-Business], [online]. Available at: https://biz.liga.net/ekonomika/all/article/vlasti-pomogli-biznesu-no-etogo-malochego-ne-uchel-antikoronavirusnyy-paket-razbor.

13. "«Vyzhyty u karantyn»: yak riatuietsia malyi i serednii biznes i choho ochikuie vid derzhavy' ["Survive in quarantine": how small and medium-sized businesses are saved and what theyexpect from the state]. (2020). Radio Svoboda [Radio Svoboda], [online]. Available at: https://www.radiosvoboda.org/a/karantynbiznes-zbytky-dergava/30523993.html.

14. 'Yak zhyve molod Ukrainy pid chas COVID-19?' [How does Ukrainian youth live in the times of COVID-19?]. (2020). The UNDP, [online]. Available at: https://www.ua.undp.org/content/kraine/uk/home/library/democratic_governance /COVID-19-impact-on-youth-in-Ukraine.html. 


\section{THE SITUATION OF YOUTH ENTREPRENEURSHIP UNDER QUARANTINE RESTRICTIONS (ACCORDING TO THE RESULTS OF RESEARCH 2020)}

\section{Siryy Evgen}

Doctor of Social Sciences, Professor,

State Institution "State Institute of Family and Youth Policy",

Kyiv, Ukraine

ORCID: 0000-0003-3396-8168

socio1@ukr.net

The material highlights one of the current problems of youth entrepreneurship and self-employment in Ukraine - their situation and prospects in the context of quarantine restrictions in assessing the role of the state. De jure, the state has responded to certain challenges of the pandemic in the development of small business (youth): from the legal framework, programs, organizations, to certain specific measures of a local nature. However, appropriate measures by the authorities, especially in comparison with other countries, require greater efficiency. These conclusions are confirmed by the data of some relevant sociological studies presented in the article. The empirical material shows the main trends in the development of small business (youth) under quarantine restrictions, assessment of the role of the state in solving relevant problems.

Key words: pandemic; COVID-19; problems of youth entrepreneurship development; state aid; evaluation.

$\overline{\text { (с)ірий Є. В., } 2021}$ 


\section{ПОЛОЖЕНИЕ МОЛОДЕЖНОГО ПРЕДПРИНИМАТЕЛЬСТВА В УСЛОВИЯХ КАРАНТИНА (ЗА РЕЗУЛЬТАТАМИ ИССЛЕДОВАНИЯ 2020 ГОДА)}

\section{Сирый Евгений Владимирович}

доктор социологических наук, профессор, Государственный институт семейной и молодежной политики, 2. Киев, Украина

ORCID: 0000-0003-3396-8168

socio1@ukr.net

В материале освещается одна из сегодняшних проблем молодежного предпринимательства и самозанятости в Украине - их положение и перспективы в условиях карантина в оценке ролевой участия государства. Де-юре правительство отреагировало на определенные вызовы пандемии в развитии малого предпринимательства (молодежного): от законодательной базы, программ, организаций, в отдельных конкретных мероприятий локального характера. Однако соответствующие меры со стороны власти, особенно по сравнению с другими странами, требуют большей эффективности. Эти выводы подтверждаются данными отдельных соответствующих социологических исследований, представленных в статье. На эмпирическом материале показаны основные тренды в развитии малого бизнеса (молодежного) в условиях карантина, оценку ролевой участия государства в решении соответствующих проблем.

Ключевые слова: пандемия; COVID-19; проблемы развития молодежного предпринимательства; государственная помощь; оценка. 